\title{
Knoop hardness of enamel and shear bond strength of brackets bonded with composite resin with and without fluoride
}

Silvia Amélia Scudeler Vedovello', Marcelo Grigoletto ${ }^{2}$, Mário Vedovello Filho', Heloísa Cristina Valdrighi', Mayury Kuramae'

Objective: The aim of this study was to evaluate the Knoop hardness of enamel, shear bond strength and failure pattern (adhesive, bracket/resin interface or mixed) after bonding and debonding brackets, using resin composite with fluoride (Ortho Lite Cure, Ortho Source ${ }^{\circledR}$ ) and without fluoride (Orthobond, Morelli ${ }^{\circledR}$ ).

Methods: Fragments $(6 \mathrm{~mm}$ x $6 \mathrm{~mm}$ ) of 40 bovine incisor crowns were embedded in acrylic self-polymerizing resin. The Knoop hardness measurements were performed before and after bonding metal brackets. The specimens were divided into two groups, according to composite resin: with fluoride (Ortho Lite Cure, Ortho Source ${ }^{\circledR}$ ) and without fluoride (Orthobond, Morelli ${ }^{\circledR}$ ). After bonding, the specimens were submitted to demineralization and remineralization cycling for 14 days. Shear bond strength testing was performed in a universal test machine (EMIC), at $5 \mathrm{~mm} / \mathrm{min}$ crosshead speed.

Results: There was no significant difference in shear bond strength between Groups I and II. After demineralization and remineralization procedures (DE/RE), the specimens bonded with Ortho Lite Cure showed higher Knoop hardness than Orthobond. For both groups there was predominance of failure at bracket/resin interface.

Conclusion: specimens bonded with fluoride resin composite showed higher microhardness after DE/RE cycling than those bonded with resin composite without fluoride, although no difference in shear bond strength was found.

Keywords: Composite resins. Orthodontic brackets. Hardness. Shear strength.

${ }^{1} \mathrm{PhD}$ Professor of the Post-Graduation Program in Dentistry, concentration in Orthodontics, UNIARARAS.

${ }^{2} \mathrm{MSc}$ in Orthodontics, UNIARARAS
How to cite this article: Vedovello SAS, Grigoletto M, Vedovello Filho M, Valdrighi HC, Kuramae M. Knoop hardness of enamel and shear bond strength of brackets bonded with composite resin with and without fluoride. Dental Press J Orthod. 2012 July-Aug;17(4):21.el-5.

Submitted: May 12, 2009 - Revised and accepted: April 12, 2010

» The authors report no commercial, proprietary or financial interest in the products or companies described in this article.

Contact address: Mário Vedovello Filho

Av. Maximiliano Baruto, 500, Jd. Universitário - Araras/SP, Brazil

Zip code: 13.607-339 - E-mail: vedovello@terra.com.br 


\title{
Dureza Knoop do esmalte e resistência ao cisalhamento de braquetes colados com resina composta com e sem flúor
}

\author{
Silvia Amélia Scudeler Vedovello', Marcelo Grigoletto ${ }^{2}$, Mário Vedovello Filho', Heloísa Cristina Valdrighi', Mayury Kuramae ${ }^{1}$
}

Objetivo: o propósito deste estudo foi avaliar a dureza Knoop do esmalte, resistência ao cisalhamento e padrão de falha (adesiva; interface braquete/resina; e mista) após a colagem e descolagem de braquetes, utilizando uma resina composta com flúor (Ortho Lite Cure, Ortho Source ${ }^{\circledR}$ ) e uma sem flúor (Orthobond, Morelli ${ }^{\circledR}$ ).

Métodos: fragmentos ( $6 \mathrm{~mm}$ x $6 \mathrm{~mm}$ ) de 40 coroas de incisivos bovinos foram embutidos em resina acrílica autopolimerizável. A dureza Knoop foi avaliada antes e após a colagem dos braquetes metálicos. Os corpos de prova foram divididos em dois grupos: resina com flúor (Ortho Lite Cure, Ortho Source ${ }^{\circledR}$ ) e resina sem flúor (Orthobond, Morelli $\left.{ }^{\circledR}\right)$. Após a colagem, os corpos de prova foram submetidos ao ciclo de desmineralização e remineralização durante 14 dias, e submetidos ao ensaio de resistência ao cisalhamento em máquina universal de ensaios EMIC, com velocidade de $0,5 \mathrm{~mm} / \mathrm{min}$.

Resultados: o ensaio de resistência de união mostrou que não houve diferença significativa entre os grupos. Após o processo de desmineralização e remineralização, os corpos de prova colados com a resina composta com flúor apresentaram maior dureza, comparados aos colados com resina sem flúor. Para ambos os grupos houve predominância de falhas na interface resina/braquete.

Conclusão: os corpos de prova colados com a resina composta com flúor apresentaram maior microdureza após os processos de desmineralização e remineralização, comparados aos colados com resina composta sem flúor, porém sem diferença para a resistência de união ao cisalhamento.

Palavras-chave: Braquetes. Resistência ao cisalhamento. Resinas compostas.

${ }^{1}$ Professores Doutores do Programa de Pós-graduação em Odontologia, área de concentração Ortodontia, do Centro Universitário Hermínio Ometto UNIARARAS/SP.

${ }^{2}$ Mestre em Ortodontia pelo Centro Universitário Hermínio Ometto - UNIARARAS.
Como citar este artigo: Vedovello SAS, Grigoletto M, Vedovello Filho M, Valdrighi HC, Kuramae M. Knoop hardness of enamel and shear bond strength of brackets bonded with composite resin with and without fluoride. Dental Press J Orthod. 2012 July-Aug;17(4):21.el-5.

Enviado em: 12 de maio de 2009 - Revisado e aceito: 12 de abril de 2010

» Os autores declaram não ter interesses associativos, comerciais, de propriedade ou financeiros que representem conflito de interesse nos produtos e companhias descritos nesse artigo.

Endereço para correspondência: Mário Vedovello Filho Av. Maximiliano Baruto, 500, Jd. Universitário - Araras/SP - CEP: 13.607-339 E-mail: vedovello@terra.com.br 


\section{INTRODUCTION}

During treatment planning, the problems that can arise from bonding accessories are of fundamental importance for a successful outcome. ${ }^{15,22}$ Since the introduction of methods for cementation and bonding orthodontic accessories to dental enamel, various modifications have occurred. The acid etching technique, introduced by Buonocore, ${ }^{8}$ in 1955, demonstrated the possibility of obtaining micromechanical retention of acrylic restorative materials to the tooth surface. ${ }^{10,20}$

Caries is a dynamic process, resulting from microbial metabolism on the tooth surface, which may result in mineral loss due to the imbalance between the demineralization and remineralization process, and subsequently, in cavitation. ${ }^{12}$ To diminish the incidence of caries around orthodontic brackets, materials with fluoride releasing capacity, such as glass ionomer cements, were introduced. Glass ionomer cement was introduced in restorative dentistry in 1972, showing properties of chemical bond to enamel and dentin, as well as to non precious metals and plastics. ${ }^{15,16}$ In addition to acting as a reservoir for fluoride released by means of ionic exchanges without any loss of resistance, it can be stored for a long time. ${ }^{14}$

Afterwards, fluoride releasing composites were introduced on the market due to their better resistance and esthetic properties, when compared with glass ionomer cements. Due to the greater difficulty with cleaning caused by fixed orthodontic appliance, and the increase in the risk of caries incidence, ${ }^{18}$ some manufacturers developed hybrid resins that release fluoride. ${ }^{20}$ Among these, there is Ortho Lite Cure (Ortho Source), a resin composite for bracket bonding which contains fluoride in its composition.

The beneficial effect of fluoride is evident in the control of white spot lesions and for improving oral health during orthodontic treatment. The use of materials that do not depend on patient cooperation during orthodontic treatment is of fundamental importance in diminishing the risk of caries and increasing treatment success. Therefore, the purpose of this study was to evaluate the Knoop hardness of enamel, shear bond strength and failure pattern (adhesive, bracket/composite interface or mixed) after bonding and debonding brackets, with the use of resin composite with fluoride (Ortho Lite Cure, Ortho Source ${ }^{\circledR}$ ) and without fluoride (Orthobond, Morelli ${ }^{\circledR}$ ).

\section{MATERIAL AND METHODS}

Forty bovine incisor crowns were sectioned with double-faced diamond disks under water cooling, to obtain fragments measuring $6 \mathrm{~mm} \mathrm{X} 6 \mathrm{~mm}$. The fragments were embedded in $\mathrm{PVC}^{\circledR}$ cylinders with polystyrene resin. After 24 hours, the test specimens were flattened in a polishing machine (Arapol 2v, Arotec S/A Ind. Com. Osasco/SP, Brazil), with water abrasive paper of decreasing granulation (400, 600 and 1000), under constant water cooling, and polished with $6,3,1 / 2$ and $1 / 4 \mu \mathrm{m}$ diamond paste and felt disc, under mineral oil cooling.

Knoop microhardness analysis of the enamel was performed in a microhardness tester model HVS 1000 A (Panambra/SP) with a $25 \mathrm{~g}$ load for $5 \mathrm{~s},{ }^{19}$ before and after bracket removal. Nine initial hardness readouts were taken on each enamel fragment before bracket bonding. The indentations were made in one of the four edges of the fragment, which was duly identified, so that after the bracket was removed and the indentations were made, they would be made in the same sites as those of the initial indentations (Fig 1).

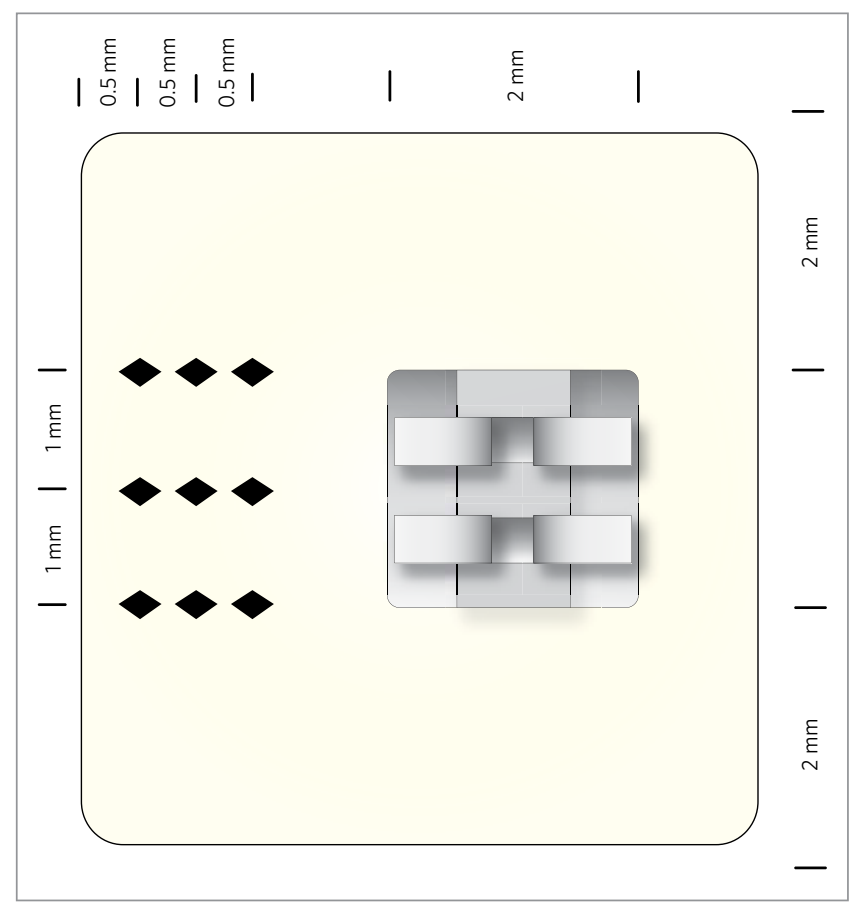

Figure 1 - Diagrammatic drawing of the Knoop hardness readout region. 
After this, the fragments were submitted to prophylaxis with pumice stone and water, using a brush driven by a low speed motor, followed by washing under running water and drying with a light jet of compressed air. Next, adhesive tape was placed over the surface of each test specimen in which the indentations had been made, so that the adhesive and composite resin would not flow into this region. The enamel was etched with $37 \%$ phosphoric acid, applied to an area corresponding to the size of the base of the metal bracket for the maxillary central incisor (Roth Light $0.56 \times 0.76 \mathrm{~mm}, 0.022 \mathrm{x}$ 0.030 -in at $0^{\circ}$ torque and $0^{\circ}$ angulation, Morelli ${ }^{\mathrm{TM}}$ ), for 30 seconds, washed and dried with air jets for $20 \mathrm{sec}-$ onds. The test specimens were divided into two groups (n=20): Group I - bonded with composite resin Orthobond (Morelli), without fluoride; and Group II - with composite Ortho Lite Cure (Ortho Source ${ }^{\mathrm{TM}}$ ), with fluoride. To proceed with bonding, the resin composite was applied on the bracket bases, which were manually pressed onto the bovine incisors, and composite excesses were removed with an exploratory probe. Light activation was performed for $40 \mathrm{~s}$, being $10 \mathrm{~s}$ on each face of the bracket, using an halogen light appliance (XL2500, 3M/ESPE).

The demineralization and remineralization processes were induced 24 hours after bracket bonding. The test specimens underwent the demineralization process (6 hours) and remineralization (18 hours) in an artificial solution for a period of two weeks. ${ }^{22}$

Forty-eight hours after concluding the demineralization and remineralization process, the shear bond strength test was performed in a universal test machine EMIC (Equipamentos e Sistemas de Ensaio Ltda, model DL 2000, São José dos Pinhais - PR, Brazil), using a chisel, at a test speed of $0.5 \mathrm{~mm} / \mathrm{min}$.

After the shear bond strength test, the samples were analyzed under a stereoscopic loupe (CQA, model EK3ST), at 20X magnification, to determine the failure mode: adhesive (no composite remainder on enamel), composite/bracket (all the composite resin remained adhered to the enamel) and mixed (part of the composite was adhered to the enamel and the other part to the bracket). All the procedures were carried out by one single operator. Knoop hardness was verified again after debonding. The microhardness and shear bond strength data were submitted to the Analysis of Variance and Tukey tests $(\mathrm{p}<0.05)$.

\section{RESULTS}

The results presented in Table 1 showed that there was no statistically significant difference for the initial hardness values ( $>0.05)$. However, the test specimens that received the composite with fluoride (Ortho Lite Cure) presented a significantly higher final microhardness when compared with those treated with resin composite without fluoride (Orthobond) $(\mathrm{p}<0.05)$. Analysis of the results indicated that there was a significant reduction in the hardness values after the demineralization and remineralization procedure, both in the test specimens in Group I and Group II (Table 1).

The shear bond strength test, presented in Table 2 , shows that there was no statistically significant difference between the samples bonded with Ortho Lite Cure and Orthobond ( $p>0.05)$.

Analysis of the failure mode showed that the test specimens in Groups I and II presented predominance of failures at the composite/bracket interface (55\% and $50 \%$, respectively).

Table 1 - Knoop microhardness (KHN) means (standard deviation) before and after the demineralization and remineralization cycles.

\begin{tabular}{ccc} 
Time & Orthobond & Ortho Lite Cure \\
\hline Initial & $266.57(34.23)^{\mathrm{a}, \mathrm{A}}$ & $266.33(33.58)^{\mathrm{a}, \mathrm{A}}$ \\
Final & $31.78(13.02)^{\mathrm{b}, \mathrm{B}}$ & $45.83(11.64)^{\mathrm{a}, \mathrm{B}}$ \\
\hline
\end{tabular}

Means followed by distinct lower case letters in line and capital letter in column differ statistically at the level of significance of $95 \%$.

Table 2 - Shear bond strength (N) means (standard deviation) after demineralization and remineralization cycling.

Orthobond

$65.13(25.82)^{a}$

Ortho Lite Cure

$57.69(20.41)^{\text {a }}$

Means followed by distinct letters in line differed statistically at the level of significance of $5 \%$.

Table 3 - Failure mode after shear bond strength test (\%).

\begin{tabular}{ccccc} 
Resin & Adhesive & Resin/bracket & Mixed & Total \\
\hline Orthobond & $3(15 \%)$ & $11(55 \%)$ & $6(30 \%)$ & $20(100 \%)$ \\
Ortho Lite Cure & $8(40 \%)$ & $10(50 \%)$ & $2(10 \%)$ & $20(100 \%)$ \\
\hline
\end{tabular}




\section{DISCUSSION}

Dental caries occurs due to the imbalance between demineralization and remineralization, and the dissolution is caused by organic acids produced by bacterial plaque, which is difficult to remove due to the presence of orthodontic appliances., ${ }^{3,18,22}$ White spot lesions evolve in four weeks, therefore the orthodontic accessories must be carefully examined during every visit. In addition to this, a preventive program with fluoride application must be instituted. ${ }^{18}$ In the initial periods, loss of surface consistency during demineralization, ${ }^{17,18}$ as well as greater and faster accumulation of bacterial plaque occurs. ${ }^{24}$

At present, the material most used for bracket bonding is resin composite, which increases the possibility of white spots appearing. Moreover, the need to decalcify the enamel with phosphoric acid previous to resin composite application makes the enamel more susceptible to the onset of white spots. Therefore, the application of varnish with a high fluoride content is recommended, but the efficacy of this procedure is questionable. The use of a thin layer of fluoride releasing sealant on the vestibular surface of teeth, applied under the resin composite for bonding brackets, could be indicated for the areas susceptible to caries. ${ }^{2,13}$

Fluoride release provides an additional advantage to the bond system, as it minimizes decalcification around orthodontic brackets ${ }^{12}$ which could have a significant effect, particularly in orthodontic patients whose oral hygiene is deficient. ${ }^{5}$ Several researches have indicated that the use of fluoride leads to a decrease in the incidence of carious lesions, particularly when fluoride ions are easily available in the oral medium. More specifically, the presence of fluoride should diminish the ionic loss from the dental structure until the $\mathrm{pH}$ of plaque reaches 4.5, which has a beneficial effect on the remineralization process. But before reaching a critically low $\mathrm{pH}$ level, the availability of fluoride ions in the oral medium should promote remineralization., ${ }^{1,11,16,22}$

Knoop hardness tests are frequently used to verify the degree of tooth enamel mineralization ${ }^{6}$. According to the methodology used, the resin composite without fluoride (Orthobond, Morelli) presented significantly lower hardness in comparison to the resin with fluoride (Ortho Lite Cure, Ortho Source). Fluoride has a protective effect against demineralization caused by caries and erosion. ${ }^{23,25,26}$ Hydroxyapatite can be dissolved below the critical $\mathrm{pH}$ (which is low for hydroxyapatite), but the ions released may be re-precipitated as fluorapatite or fluoridated apatite in the presence of low concentrations of fluoride ions in solution. ${ }^{25} \mathrm{In}$ the presence of high concentrations (>100 ppmF), calcium fluoride is formed and acts as a reservoir of fluoride on the tooth surface. Therefore, when the enamel is submitted to cyclic changes of $\mathrm{pH}$ in the presence of fluoride, remineralization occurs ${ }^{24}$ providing higher hardness values in the test specimens bonded with the fluoride-containing resin Ortho Lite Cure.

The sheer bond strength test results showed that there was no statistically significant difference between the test specimens bonded with Ortho Lite Cure and Orthobond. These results are in agreement with the results presented by Pascotto, ${ }^{20}$ in 2002, in which no alterations were found in the bond strength of hybrid resins that release fluoride. Reynolds ${ }^{21}$ found that the shear bond strength values for adequate bracket bonding must be between 60 and $80 \mathrm{kgF} / \mathrm{cm}^{2}$. With the conversion of the shear bond strength values for the Orthobond and Ortho Lite Cure resins, the values found in this study were $9 \mathrm{MPa}$ and $8 \mathrm{Mpa}$, respectively. These results show that both resins presented higher shear bond strength than the values proposed by Reynolds.

The improved quality of the cements available nowadays and the greater sophistication of the orthodontic arsenal, with regard to the adaptation of accessories, have provided very satisfactory results 9 . Nevertheless, the results of this study indicate that a significant percentage of failures occur at the resin/ bracket interface (55\% and 50\%, for Groups I and II, respectively). These data are in agreement with those reported by some authors, considering that the failures in bonds are observed at the bracket/resin interface, in resin or at the resin/enamel interface, with tooth fracture rarely being observed. ${ }^{7}$

The composite/bracket base interface can be considered the weak link in the bonding system, due to the greater occurrence of failures at these sites at clinical situations. ${ }^{7}$ The interaction between composite resin and enamel was more efficient. This is due to the larger area of contact existent between these two surfaces, created by the microporosities left in enamel by phosphoric acid etching. 
The application of a primer before the composite for bonding enables a more effective bond by the closer interaction between the composite resin and the enamel. The composite/bracket interaction is more fragile, as the strength is obtained by the union of the resin and the bracket mesh. The smaller contact area between these surfaces provides a weaker interaction, so that the majority of fractures are located at the composite/bracket interface. Nevertheless, fractures at the bracket/adhesive interface or within the adhesive are favorable, as the bonding material remains adhered to the tooth, and can be removed with rotary instruments, preventing damage to the enamel.

Fajen et al, ${ }^{11}$ in 1990, verified that the bond strength of glass ionomer cements was significantly lower than that of composite. The major, clinically proved, disadvantage of glass ionomer cements is the greater possibility of brackets debonding during orthodontic mechanotherapy, which may compromise the conclusion and success of treatment. ${ }^{9}$ Thus, the higher bond strength of composite, associated with the beneficial effects on caries prevention by fluoride release, is an excellent alternative available to orthodontists for use as orthodontic bonding material.

\section{CONCLUSION}

Based on the methodology used and the results obtained in the present study, it was concluded that:

1. There was no significant difference in the shear bond strength between the Orthobond and Ortho Lite Cure resin composites.

2. The test specimens bonded with resin composite with fluoride Ortho Lite Cure presented higher microhardness values after the demineralization and remineralization processes, when compared with the test specimens bonded with the resin composite without fluoride Orthobond.

3. There was predominance of failures at the composite/bracket interface for the two resin composites.

\section{REFERENCES}

1. Aasrum E, Ng'ang'a PM, Dahm S, Ogaard B. Tensile bond strength of orthodontic brackets bonded with a fluoride-releasing light-curing adhesive. An in vitro comparative study. Am J Orthod Dentofacial Orthop. 1993 Jul;104(1):48-50.

2. Banks PA, Richmond S. Enamel sealants: a clinical evaluation of their value during fixed appliance therapy. Eur J Orthod. 1994 Feb;16(1):19-25.

3. Benson PE, Shah AA, Millett DT, Dyer F, Parkin N, Vine RS. Fluorides, orthodontics and demineralization: a systematic review. J Orthod. 2005 Jun;32(2):102-14.

4. Bertoz FA, Komatsu J, Okida RC, Mendonça MR. Ionômero de vidro como meio cimentante de braquetes: estudo clínico. Ortodontia. 1991 Jan-Abr;24(1):41-3.

5. Bishara SE, Soliman M, Laffoon JF, Warren J. Shear bond strength of a new high fluoride release glass ionomer adhesive. Angle Orthod. 2008 Jan;78(1):125-8.

6. Borges AFS, Bitar RA, Kantovitz KR, Correr AB, Martin AA, Puppin-Rontani RM New perspectives about molecular arrangement of primary and permanent dentin Appl Surf Sci. 2007 Dec;254(5):1498-505

7. Bryant S, Retief DH, Russell CM, Denys FR. Tensile bond strengths of orthodontic bonding resins and attachments to etched enamel. Am J Orthod Dentofacial Orthop. 1987 Sep:92(3):225-31..

8. Buonocore MG. A simple method of increasing the adhesion of acrylic filling materials to enamel surfaces. J Dent Res. 1955 Dec;34(6):849-53.

9. Coreil MN, McInnes-Ledoux P, Ledoux WR, Weinberg R. Shear bond strength of four orthodontic bonding systems. Am J Orthod Dentofacial Orthop. 1990 Feb;97(2):126-9.

10. Correr Sobrinho L, Consani S, Sinhoretti MAC, Correr GM, Consani RLX. Avaliação da resistência ao cisalhamento na colagem de bráquetes, utilizando diferentes materiais. Rev ABO Nac. 2001 Jun-Jul;9(2):157-62.

11. Fajen VB, Duncanson MG Jr, Nanda RS, Currier GF, Angolkar PV. An in vitro evaluation of bond strength of three glass ionomer cements. Am J Orthod Dentofacial Orthop. 1990 Apr;97(4):316-22

12. Farhadian N, Miresmaeili A, Eslami B, Mehrabi S. Effect of fluoride varnish on enamel demineralization around brackets: an in-vivo study. Am J Orthod Dentofacial Orthop. 2008 Apr;133(4 Suppl):S95-8.

13. Geiger AM, Gorelick L, Gwinnett AJ, Benson BJ. Reducing white spot lesions in orthodontic populations with fluoride rinsing. Am J Orthod Dentofacial Orthop. 1992 May;101(5):403-7.
14. Hamula W, Hamula DW, Brower K. Glass ionomer update. J Clin Orthod. 1993 Aug;27(8):420-5

15. King L, Smith RT, Wendt SL Jr, Behrents RG. Bond strengths of lingual orthodontic brackets bonded with light-cured composite resins cured by transillumination. Am J Orthod Dentofacial Orthop. 1987 Apr;91(4):312-5.

16. Mizrahi E. Glass ionomer cements in orthodontics--an update. Am J Orthod Dentofacial Orthop. 1988 Jun;93(6):505-7.

17. O'Brien KD, Read MJ, Sandis. A visible light-activated direct-bonding material: an in vivo comparative study. Am J Orthod Dentofacial Orthop. 1989 Apr;95(4):348-51.

18. Ogaard B, Rølla G, Arends J. Orthodontic appliances and enamel demineralization. Part 1. Lesion development. Am J Orthod Dentofacial Orthop. 1988 Jul;94(1):68-73.

19. Palti DG, Machado MA, Silva SM, Abdo RC, Lima JE. Evaluation of superficial microhardness in dental enamel with different eruptive ages. Braz Oral Res. 2008 Oct-Dec;22(4):311-5.

20. Pascotto RC. Materiais de colagem e cimentação em ortodontia. Parte II. Sistemas adesivos resinosos. Rev Dental Press Ortod Ortop Facial. 2002 MaioJun;7(3):121-28.

21. Reynolds IR. A review of direct orthodontic bonding. Br J Orthod. 1975;3(2):171-8.

22. Romano FL, Tavares SW, Ramalli EL, Magnani MBBA, Nouer DF. Análise in vitro da resistência ao cisalhamento de braquetes metálicos colados em incisivos bovinos e humanos. Rev Dental Press Ortod Ortop Facial. 2004 Nov-Dez;9(6):63-9.

23. Schlueter N, Ganss C, Mueller U, Klimek J. Effect of titanium tetrafluoride and sodium fluoride on erosion progression in enamel and dentine in vitro. Caries Res. 2007;41(2):141-5.

24. Silva Filho OG, Castro DM, Castro RM, Lauris RCMC. Experiência clínica com o "Vitrebond" para colagem direta dos incisivos permanentes no estágio de dentadura mista. Ortodontia. 2000 Set-Dez;33(3):26-34.

25. ten Cate JM. Review on fluoride, with special emphasis on calcium fluoride mechanisms in caries prevention. Eur J Oral Sci. 1997 Oct;105(5 Pt 2):461-5.

26. Vieira A, Jager DH, Ruben JL, Huysmans MC. Inhibition of erosive wear by fluoride varnish. Caries Res. 2007;41(1):61-7. 